UDK $577.1: 61$

ISSN 1452-8258

J Med Biochem 40: 390-394, 2021

\title{
GENE POLYMORPHISM OF 3'APO-VNTR IN EGYPTIANS WITH CORONARY ARTERY DISEASE
}

\author{
POLIMORFIZAM 3'APO-VNTR GENA U EGIPĆANA \\ SA KORONARNIM ARTERIJSKIM OBOLJENJEM
}

\author{
Rehab Elmougy \\ Division of Biochemistry, Chemistry Department, Faculty of Science, Mansoura University, \\ Mansoura 35516, Egypt
}

\begin{abstract}
Summary
Background: Coronary artery diseases (CAD) are big health problem in both developed and developing countries. It is considered one of the main causes of death in the world. Dyslipidemia increases the risk of CAD incidences. It is aimed in this worktop study the impact of 3'APOBVNTRgene on CAD incidences.

Methods: Eighty CAD patients and ninety-three healthy volunteers are enrolled in this study. Lipid parameters were estimated in both groups and PCR technique has been performed to analyze 3'APOB-VNTR gene polymorphism.

Results: The genotypes 31/31, 31/37, 37/37 and 31/44 are more predominant in both groups. The frequency of $24 / 31$ in CAD patients is (0.137) while it is completely absent in the control group. Our results show that there is an increase in the frequency of various genotypes (e.g., $17 / 31$ and $21 / 34$ genotypes) in the control group compared to theca patients group.

Conclusions: 3'APOB-VNTR gene could probably be considered a risk factor for CAD incidences and may help to early diagnose them.
\end{abstract}

Keywords: coronary artery disease, Apo B, dyslipidemia, genetics, PCR

\section{Kratak sadržaj}

Uvod: Koronarno arterijsko oboljenje (CAD) je velik zdravstveni problem kako u razvijenim tako i u nerazvijenim zemljama. Smatra se da je jedan od glavnih uzroka smrtnosti u svetu. Dislipidemija povećava rizik od učestalosti CAD. Cilj ovog rada je bio ispitivanje uticaja 3'APOB-VNTR gena na učestalost CAD.

Metode: Ovo poučavanje obuhvatilo je osamdeset CAD pacijenata i devedeset tri zdrava volontera. $U$ obe grupe određivani su lipidni parametri a primenom PCR tehnike analiziran je genetski polimorfizam 3'-APOB-VNTR

Rezultati: $U$ obe grupe bili su predominantni geni 31/31, 31/37, 37/37 i 31/44. Učestalost 24/31 u CAD pacijenata je bila 0,137 , dok je u potpunosti izostala kod kontrolne grupe. Naši rezultati pokazuju da postoji povećanje u učestalosti različitih genotipova (npr. 17/31 i 21/34) u kontrolnoj grupi u poređenju sa grupom pacijenata.

Zaključak: 3'APOB-VNTR gen može se najverovatnije smatrati kao faktor rizika za učestalost CAD i može se koristiti za ranu dijagnozu.

Ključne reči: koronarno arterijsko oboljenje, Apo B, dislipidemija, genetika, PCR 


\section{Introduction}

Cardiovascular diseases are a collection of heartand blood vessels-related diseases that are globally common. Among them are coronary artery diseases that are considered one of the main causes of mortality on the globe $(1,2)$. Hypertension, diabetes mellitus and obesity are the most traditional risk factors for CAD. Moreover, the accumulation of lipids (e.g., cholesterol and triglycerides due to some environmental or genetic factors) in blood is a principal cause of CAD incidences (3). Also, there is a strong relationship between cardiomyopathy and dyslipidemia (4). The literature shows that controlling cholesterol and triglyceride in blood might be helpful in reducing the individuals' susceptibility to the disease (5).

Apolipoprotein B (ApoB) is an important component of lipoproteins (LDL- and VLDL-cholesterol) (6) LDL is responsible for carrying cholesterol to cells that need it (7). A strong correlation between the levels of $A p o B$ and $L D L$ indicates that $A p o B$ may be a main cause of $C A D$ incidences. The $A p o B$ gene is located on the chromosome $2(8,9)$. Different polymorphisms are reported at the ApoB gene. One of these polymorphisms is a variable number of tandem repeats (VNTR) at the $3^{\prime}$ end. The polyadenylation and processing of the mRNA transcript of ApoB-100 are thought to be influenced by 3'APOB-VNTR (10).

The present work aims to study the impact of 3'APOB-VNTRon the incidence of CAD in Egyptian population.

\section{Materials and Methods}

Eighty CAD patients with mean ( \pm standard deviation) age 53.5 ( \pm 9.0) years and ninety-three healthy participants, whose mean ( \pm standard deviation) age is 45.1 ( \pm 7.1 ) years, were included in the present study. Subjects having either hepatitis B or hepatitis $C$ virus were excluded from the study. None of the control subjects had any signs or symptoms suggesting CAD. Based on medical history and CAD questionnaire, all control subjects were free from any other diseases.

Blood samples. The local Ethics Committee approved the study and informed consent was obtained from each participant. Fasting whole blood samples $(5 \mathrm{~mL})$ were collected from the subjects under investigation (patients and controls). The blood sample was divided into two parts, one part delivered to plain tubes and allowed to clot for $10 \mathrm{~min}$, centrifuged and the separated serum was used to analyze the levels of cholesterol, triglycerides and HDL-cholesterol. The second part of the whole blood was taken in EDTA coated tubes for DNA extraction. PCR technique on these DNA samples was applied

Biochemical analyses. Total cholesterol (11) and triglyceride $(12,13)$ were determined by standard enzymatic methods. High-density lipoprotein (HDL) was assayed by selective precipitation with phosphotungestic acid-magnesium chloride (14). VLDL-cholesterol level has been calculated using the formula of Tunali and Yanardag (15), while LDL-cholesterol level and atherogenic index have been calculated using the formula Muruganandan et al. (16) as follows

VLDL cholesterol $=\frac{\text { Triglyceride }}{5}$,
LDL cholesterol $=$ Total cholesterol $-\mathrm{HDL}$ cholesterol $-\frac{\text { Triglyceride }}{5}$,
Atherogenic index $=\frac{\text { Total cholesterol }-\mathrm{HDL} \text { cholesterol }}{\mathrm{HDL} \text { cholesterol }}$

Determination of genotypes. Genomic DNA was extracted from whole blood using Qiagenspin columns.

Determination of $3^{\prime} A P O B-V N T R$. The amplification of 3'APOB-VNTRby PCR was carried out using a forward and reverse primer. The forward primer sequence was 5'-ATGGAAACGGAGAAATTATG$3^{\prime}$, while the reverse primer sequence was the $5^{\prime}$ CCTTCTCACTTGGCAAATAC-3'. Each reaction was done with $100 \mathrm{ng}$ of genomic DNA, 1.0 $\mu \mathrm{L}$ of each primer (20 pmol), $5 \mu \mathrm{L}$ of $10 \mathrm{x}$ buffer solution, $4 \mu \mathrm{L}$ dNTP and $1.0 \mu \mathrm{L}(2 \mathrm{U})$ Taq polymerase in a total volume of $50 \mu \mathrm{L}$. The PCR program for the amplification has been executed according to that described in Ruixing et al. (17).

Genotyping of the 3'APOB-VNTR polymorphism. $15 \mu \mathrm{L}$ of amplified DNA were run on agarose gel to separate the $3^{\prime}$ VNTR alleles. The gel was stained with ethidium bromide and visualized using UV. The formula used in the calculation of the number of tandem repeats is: repeat number $=$ (fragment length (bp) - 138 bp)/15 bp (17).

Statistical analysis. Statistical analysis was performed with the statistical discovery software JMP 9. Quantitative data were presented as mean and SD. Qualitative data were presented as frequencies. Oneway analysis of variance (ANOVA) test was used to compare variables with a normal distribution and significance was accepted at $\mathrm{P}<0.05$.

\section{Results}

Table I shows that there is a highly significant increase in the levels of cholesterol, triglycerides, LDL-cholesterol, VLDL-cholesterol and atherogenic index in CAD patients in comparison with their levels in the control group. However, a significant decrease has been found in the level of HDL-cholesterol in patients compared to control subjects.

The frequency of $A p o B$ genotypes in both groups (patients and controls) is shown in Table II. The genotypes $31 / 31,31 / 37,37 / 37$ and $31 / 44$ are more predominant in both groups. 
Table I Demographic characteristics of both CAD cases and healthy volunteers.

\begin{tabular}{|l|c|c|c|}
\hline Parameter & $\begin{array}{c}\text { Control } \\
\text { Mean } \pm \text { SD }\end{array}$ & $\begin{array}{c}\text { CAD cases } \\
\text { Mean } \pm \text { SD }\end{array}$ & p-value \\
\hline Age (years) & $45.1 \pm 7.1$ & $53.5 \pm 9.0$ & $<0.0001^{*}$ \\
\hline Total cholesterol (mmol/L) & $7.11 \pm 1.28$ & $11.94 \pm 3.50$ & $<0.0001^{*}$ \\
\hline TG $(\mathrm{mmol} / \mathrm{L})$ & $2.39 \pm 0.36$ & $9.66 \pm 5.81$ & 0.101 \\
\hline HDL-cholesterol (mmol/L) & $2.15 \pm 0.29$ & $2.75 \pm 1.62$ & $<0.0001^{*}$ \\
\hline VLDL-cholesterol (mmol/L) & $0.48 \pm 0.07$ & $1.93 \pm 1.16$ & $<0.0001^{*}$ \\
\hline LDL-cholesterol $(\mathrm{mmol} / \mathrm{L})$ & $3.78 \pm 1.82$ & $7.34 \pm 3.52$ & 0.0049 \\
\hline Atherogenic index & $2.35 \pm 0.6$ & $5.1 \pm 4.3$ & \\
\hline
\end{tabular}

*SD = Standard deviation, TG = Triglyceride, HDL = High density lipoprotein, LDL = Low density lipoprotein, VLDL $=$ Very low density lipoprotein.

Table II Distribution of ApoB genotypes.

\begin{tabular}{|c|c|c|c|c|}
\hline \multirow{2}{*}{ Genotype } & \multicolumn{2}{|c|}{ Control subjects } & \multicolumn{2}{|c|}{ CAD Patients } \\
\hline & Number observed & Frequency & Number observed & Frequency \\
\hline $17 / 17$ & 1 & 0.0108 & 0 & 0 \\
\hline $17 / 24$ & 0 & 0 & 2 & 0.025 \\
\hline $17 / 31$ & 13 & 0.1398 & 0 & 0 \\
\hline $21 / 21$ & 0 & 0 & 1 & 0.0125 \\
\hline $21 / 27$ & 0 & 0 & 1 & 0.0125 \\
\hline $21 / 31$ & 2 & 0.0215 & 0 & 0 \\
\hline $21 / 34$ & 8 & 0.0860 & 0 & 0 \\
\hline $21 / 37$ & 2 & 0.0215 & 0 & 0 \\
\hline $24 / 24$ & 2 & 0.0215 & 3 & 0.0375 \\
\hline $24 / 31$ & 0 & 0 & 11 & 0.1375 \\
\hline $24 / 44$ & 0 & 0 & 1 & 0.0125 \\
\hline $27 / 27$ & 0 & 0 & 1 & 0.0125 \\
\hline $27 / 31$ & 1 & 0.0108 & 0 & 0 \\
\hline $27 / 34$ & 0 & 0 & 3 & 0.0375 \\
\hline $31 / 31$ & 8 & 0.0860 & 22 & 0.275 \\
\hline $31 / 34$ & 1 & 0.0108 & 0 & 0 \\
\hline $31 / 37$ & 19 & 0.2043 & 14 & 0.175 \\
\hline $31 / 44$ & 18 & 0.1935 & 11 & 0.1375 \\
\hline $31 / 51$ & 1 & 0.0108 & 1 & 0.0125 \\
\hline $34 / 34$ & 4 & 0.0430 & 0 & 0 \\
\hline $37 / 37$ & 10 & 0.1075 & 9 & 0.1125 \\
\hline $37 / 44$ & 2 & 0.0215 & 0 & 0 \\
\hline $44 / 44$ & 1 & 0.0108 & 0 & 0 \\
\hline
\end{tabular}

Table III Frequency distribution (percent) of ApoB alleles in normal control and CAD subjects.

\begin{tabular}{|c|c|c|c|c|}
\hline Allele & Control subjects N (\%) & CAD cases N (\%) & Chi-square value $(\mathrm{p}$-value) & OR $(95 \% \mathrm{Cl})$ \\
\hline 17 & $15(8.06)$ & $2(1.25)$ & $21.244\left(<0.0001^{*}\right)$ & $0.0815(0.019-0.35)$ \\
\hline 21 & $12(6.45)$ & $3(1.88)$ & $14.5\left(0.0001^{*}\right)$ & $0.142(0.042-0.49)$ \\
\hline 24 & $4(2.15)$ & $20(12.50)$ & $15.18\left(<0.0001^{*}\right)$ & $6.5(2.17-19.45)$ \\
\hline 27 & $1(0.54)$ & $6(3.75)$ & $4.85\left(0.0277^{*}\right)$ & $7.21(0.86-60.5)$ \\
\hline 31 & $71(38.17)$ & $81(50.63)$ & $5.42\left(0.0199^{*}\right)$ & $1.66(1.08-2.55)$ \\
\hline 34 & $17(9.14)$ & $3(1.88)$ & $9.3\left(0.0023^{*}\right)$ & $0.19(0.055-0.66)$ \\
\hline 37 & $43(23.12)$ & $32(20.00)$ & 0.4940 .482 & $0.83(0.5-1.4)$ \\
\hline 44 & $22(11.83)$ & $12(7.50)$ & 1.850 .174 & $0.6(0.29-1.26)$ \\
\hline 51 & $1(0.54)$ & $1(0.63)$ & - & - \\
\hline
\end{tabular}

$\mathrm{OR}=$ Odds ratio, $\mathrm{Cl}=$ Confidence interval. 
Table III demonstrated that there is a highly significant decrease in the frequency of the alleles 17, 21 and 34 in CAD patients in comparison with the control subjects, while there is a highly significant increase in the frequency of the alleles 24, 27 and 31 in CAD patients when compared with the control volunteers.

\section{Discussion}

CAD is a common health problem all over the world (18). The World Health Organization reported that CAD are the main causes of death for about 17.3 millions (19). There are many risk factors for CAD incidence such as hyperlipidemia, diabetes mellitus and hypertension $(20,21)$. Here, we are interested in studying ApoB gene polymorphism as a risk factor for $C A D$ incidences due to its strong relation to LDL-cholesterol.

Our results show the levels of cholesterol, triglycerides, LDL-cholesterol and VLDL-cholesterol and the atherogenic index are significantly high in CAD patients compared to the control group. This finding is in line with many previous studies $(22,23)$. The results show further that there is a significant increase in the frequency of various genotypes (like $17 / 31$ and $21 / 34$ genotypes) in the control group (with frequencies 0.1398 and 0.0860 ) than in CAD patients group (with zero frequencies). On the contrary, the frequency of 24/31 genotype in CAD patients group is 0.137 , while it completely vanishes in the control group. These results may help in the early prediction of CAD. To our best, this is the first study carried out in Egypt that focuses on investigating 3'APOB-VNTR polymorphism in Egyptian patients with CAD.

\section{References}

1. Ayatollahi H, Gholamhosseini L, Salehi M. Predicting coronary artery disease: a comparison between two data mining algorithms. BMC Public Health 2019; 19(1): 448.

2. Shabana, Shahid SU, Sarwar S. The abnormal lipid profile in obesity and coronary heart disease (CHD) in Pakistani subjects. Lipids Health Dis 2020; 19(1): 73.

3. Manandhar S, Ju S, Choi DH, Song H. Lipid-induced cardiovascular diseases. J Cardiol Cardiovasc Med 2017; 2: 085-94.

4. Sharifi-Rad J, Rodrigues CF, Sharopov F, et al. Diet, Lifestyle and Cardiovascular Diseases: Linking Pathophysiology to Cardioprotective Effects of Natural Bioactive Compounds. Int J Environ Res Public Health 2020; 17(7): 2326.

5. Laing, N, Kraus, S M, Shaboodien, G, Ntusi, NAB. An overview of the genetic basis of cardiovascular disease. SAMJ: South African Medical Journal (2019); 109(6): 364-70.
Our finding has some similarities with the results reported by Sajib et al. (24) who conducted their study on Bangladeshi patients with type 2 diabetes mellitus. The difference might be referred to the population ethnicity or the disease. In China, Hu et al. (25) reported that the genotype and allele distributions of $A p o B$ variants in Chinese children with primary nephrotic syndrome were not significantly different from the control volunteers.

There is a highly significant increase in the frequencies of some alleles (e.g., 24, 27 and 31 alleles) in $A p o B$ gene in $C A D$ patients group when compared to their correspondences in the control group. These results may support the idea that the accumulation of bad cholesterol particles in blood may attitude to genetic factors such as $A p o B$ gene and the priority to control the blood lipids levels by different ways such as control the diet, doing physical exercises and finally administration of some drugs, which may help reduce fat particles in blood.

Acknowledgements. The author would like to thank the anonymous referees as well as the editor for their invaluable comments that helped to improve the paper.

\section{Conclusion}

3'APOB-VNTRgene might be considered a risk factor in CAD incidence and might help to early diagnose CAD.

\section{Conflict of interest statement}

All the authors declare that they have no conflict of interest in this work.

6. Wang YT, Li Y, Ma YT, et al. Association between apolipoprotein $B$ genetic polymorphism and the risk of calcific aortic stenosis in Chinese subjects, in Xinjiang, China. Lipids Health Dis 2018; 17(1): 40.

7. Afonso CB, Spickett C.M. Lipoproteins as targets and markers of lipoxidation. Redox Biology 2019; 23: 101066.

8. Benn M. Apolipoprotein B levels, APOB alleles, and risk of ischemic cardiovascular disease in the general population, a review. Atherosclerosis 2009; 206(1): 17-30.

9. Benn M, Nordestgaard BG, Jensen GB, Tybjaerg-Hansen A. Improving prediction of ischemic cardiovascular disease in the general population using apolipoprotein B: the Copenhagen City Heart Study. Arterioscler Thromb Vasc Biol 2007; 27(3): 661-70.

10. Al-Bustan SA, Alnaqeeb MA, Annice BG, Ebrahim GA, Refai TM. Genetic association of APOB polymorphisms with variation in serum lipid profile among the Kuwait population. Lipids Health Dis 2014; 13: 157. 
11. Meiattini F. The 4-hydroxybenzoate / 4-aminophenazone chromogenic system. Clin Chem 1978; 24(12): 21615.

12. Buccolo G. Quantitative determination of serum triglycerides by use of enzymes. Clin Chem 1973; 19(5): 47682.

13. Fossati P, Prencipe L, Berti G. Use of 3, 5-dichloro-2hydroxybenzenesulforic acid/4-aminophenazone chromogenic system in direct enzymic assay of uric acid in serum and urine. Clinical Chem 1980; 26: 227-31.

14. Gordon T, Castelli WP, Hjortland MC, Kannel WB Drawber TR. High density lipoprotein in protective factor against coronary heart diseases: the Framingham study. Amer J Med 1977; 62: 707-14.

15. Tunali S, Yanardag R. Effect of vanadyl sulfate on the status of lipid parameters and on stomach and spleen tissues of streptozotocin-induced diabetic rats. Pharmacological Research 2006; 53(3): 271-7.

16. Muruganandan S, Srinivasan K, Gupta S, Gupta PK, Lal $J$. Effects of mangiferin on hyperglycemia and atherogenicity in streptozotocin diabetic rats. J Ethnopharmacol 2005; 97: 497-501.

17. Ruixing Y, Guangqin C, Yong W, Weixiong L, Dezhai Y, Shangling P. Effect of the 3'APOB-VNTR polymorphism on the lipid profiles in the Guangxi Hei Yi Zhuang and Han populations. BMC Med Genet 2007; 8: 45.

18. Gianazza E, Brioschi M, Fernandez AM, Banfi C. Lipoxidation in cardiovascular diseases. Redox Biol 2019; 23: 101119
19. Malakar AK, Choudhury D, Halder B, Paul P, Uddin A, Chakraborty S. A review on coronary artery disease, its risk factors, and therapeutics. J Cell Physiol 2019; 234(10): 16812-23.

20. Stewart J, Manmathan G, Wilkinson P. Primary prevention of cardiovascular disease: A review of contemporary guidance and literature. JRSM Cardiovasc Dis 2017; 6: 2048004016687211.

21. Shaima C, Moorthi P V, Shaheen N K. Cardiovascular diseases: Traditional and non-traditional risk factors. J Med Allied Sci 2016; 6(2): 46-51.

22. Reiner Ž. Hypertriglyceridaemia and risk of coronary artery disease. Nature reviews. Cardiology 2017; 14(7): 401-11.

23. Kumar L, Das A L. Assessment of serum lipid profile in patients of coronary artery disease: a case-control study. International Journal of Contemporary Medical Research 2018; 5(5): E59-E62.

24. Sajib A, Khan M A, Haque M N, Kibria K, Chowdhury A $\mathrm{K}$, Yeasmin S. Association of APOB 3 -VNTR alleles with type 2 diabetes, BMI, systolic and diastolic blood pressure. Bangladesh Journal of Medical Science 2018; 17(1): 71-7

25. Hu P, Hu B, Qin YH, Lu L, Li ZQ, Tao LQ, Pei Q, Chen J. Serum lipid abnormalities are not associated with apoB 3' VNTR polymorphism in nephrotic children. Genet Mol Res 2013; 12(1): 765-74.

Received: January 29, 2021

Accepted: March 11, 2021 